\title{
The importance of the manufacturing sector for Brazilian economic development
}

\author{
Carmem Aparecida Feijó and Marcos Tostes Lamonica
}

ABSTRACT

This article, based on Kaldor's model of the stages of development, concludes that, despite having modernized thanks to the economic liberalization process, the evolution of Brazil's industrial structure has increased the share of low-technology goods in the production matrix. The trend appreciation of the real in the initial phase of economic liberalization was positive for modernizing Brazil's technology stock; but its continuation in recent years, when there has been ample international liquidity for emerging countries, threatens the development of the national manufacturing sector. This sector could suffer a technological setback, which, according to the principle of circular cumulative causation, diminishes its capacity to forge links with other sectors of activity, and accentuates the economy's long-term external dependency.

KEYWORDS

JEL CLASSIFICATION

AUTHORS
Industrial sector, manufactured products, consumer goods, capital goods, economic development, gross domestic product, industrial statistics, economic indicators, Brazil

O11, O14, L16

Carmem Aparecida Feijó is a tenured professor at the Fluminense Federal University and research fellow at the National Council of Scientific and Technological Development (cNPq).cfeijo@terra.com.br Marcos Tostes Lamonica is an assistant professor at the Fluminense Federal University. marcostostes@hotmail.com 


\section{I}

\section{Introduction}

The controversy surrounding the role played by the manufacturing sector in the development of the Brazilian economy has intensified recently, given the finding that the sector's share in gross domestic product (GDP) has been declining on a more or less sustained basis since the 1980s, and at a faster pace since the economic stabilization of the first half of the 1990s (Marquetti, 2002; Palma, 2005; Barros and Pereira, 2008; BresserPereira, 2008; Nassif, 2008a; Oreiro and Feijó, 2010, among others). The controversy in particular concerns the effect of exchange-rate appreciation on potential industrial performance.

The appreciation of the real lasted throughout much of the 1990s and was interrupted by a change in the exchange-rate regime in January 1999. Since 2003 the Brazilian currency had been strengthening again, and the terms of trade have also been improving. Although exchange-rate appreciation benefits the productive sector by lowering the cost of imported inputs and capital goods, it also discourages exports. The repercussion on the productive structure depends on how those effects translate into higher productivity to offset the relative loss of competitiveness. Nonetheless, the effect of an over-valued exchange rate on the productive structure can only be positive if it contributes to structural change that expands the supply of products with a high incomeelasticity of exports, and reduces dependency on products that have a low income- elasticity of imports. According to Thirlwall's law, if that occurred, long-term growth capacity would be increasing; in other words the external constraint on growth would be easing.

This article analyses the extent to which the declining share of the manufacturing sector in Brazil's GDP reflects a productive restructuring process that would enable the country to move closer to the technological frontier, or else a regression in the industrial structure that is likely to reduce future growth potential. According to the traditional economic-development approach, deeper productive specialization reflects the workings of the market, so the economic liberalization that has occurred since the 1990s should have facilitated a modernization of the industrial structure, despite the preponderance of low-technology products. In contrast, the heterodox approach not only proposes a manufacturing development model based on industries of higher technological content, but it also views economic growth as determined by the momentum of an industry that is competitive in producing technology-intensive goods.

The analysis reported in this article is framed by the postulates put forward by Kaldor, who, while recognizing the importance of the manufacturing sector as a factor of economic development, showed that a more technologically sophisticated industrial structure involves more robust and complex intra- and inter-sectoral linkages, which increase potential growth. Application of the Kaldor postulates to the Brazilian case in the 1990s and first decade of the new century, supported by descriptive statistics, shows that despite the potential for modernization afforded by economic liberalization, the changing sector composition of industry reveals a process of specialization in the production of goods of low technological intensity. The appreciating trend of the Brazilian currency, following domestic-price stabilization, is identified as a key factor explaining the country's difficulty in furthering structural change to acquire a more advanced technological profile. This article contributes by showing that, over a period of two decades, the currency-appreciation trend may have had a positive influence in the initial phase of price stabilization, but that its persistence in a context of ample international liquidity puts the evolution of industry at risk

Apart from this brief introduction, this article is divided into three sections. Section II describes Kaldor's theoretical framework, which analyses the special role played by the manufacturing sector in the economicdevelopment process. Section III uses empirical arguments to characterize the changes that have occurred in Brazil's industrial structure; and section IV makes final comments. 


\section{II}

\section{Kaldor's structuralist analytical framework}

Efforts to understand the economic development process of less developed countries first appeared on economists' research agenda in the 1940s and 1950s, when the structuralist thinking started to be articulated by the Economic Commission for Latin America and the Caribbean (ECLAC). Progress in the theoretical debate turned structuralist economic policy into the defender of the industrialization of non-industrialized countries, with a view to improving their economies' participation in trade flows. In practice, late industrialization gave countries on the periphery a highly heterogeneous and relatively undiversified productive structure, in contrast to the more homogeneous and highly diversified structure of the central economies.

Apart from displaying widely varying productive structures in terms of productivity and factor remuneration, the industrialization process based on import substitution in the peripheral economies faced chronic balance of payment problems before industrialization was fully completed. ${ }^{1}$ In fact, it proved impossible to complete the process because of the external constraint on growth. Kaldor's work in the 1960s and 1970s describes how a comprehensive industrialization process ought to be adopted.

\section{A. Kaldor and the four phases of economic development}

According to Kaldor, the maturity of an economy depends on its having completed the industrial development process. Kaldor (1966) distinguishes four development phases in the industrialization process, and argues that the maturing of an "immature" economy is based on the growth of aggregate demand. ${ }^{2}$ From this standpoint, the capital accumulation generated by the industrialization process is the key variable of economic development, since it speeds up technological change to the benefit of the entire economy - as reflected in lower unit costs

\footnotetext{
1 For a more detailed historical assessment of this process in the region, see Bértola and Ocampo (2010), among others.

2 An immature economy is characterized by a large supply of labour in low-productivity sectors, which can be absorbed by more productive sectors as the industrialization process spreads towards them. Countries would attain the maturity phase when productivity levels become aligned.
}

and higher-quality export products, enabling domestic producers to compete on foreign markets.

The application of the four-phase industrial development analytical framework makes it possible to evaluate economic development according to Kaldor's principles. The scheme recognizes that a country's industrialization process can occur cumulatively, which means that the production of consumer goods would precede the production of capital goods, which, in both cases and in their initial stages, would be export-oriented, in other words targeting external demand.

The first phase of development gives rise to a domestic industry producing consumer goods, as has been seen in the industrialization process in most countries, especially Latin American ones. This stage would reduce reliance on imports of this type of good; but the domestic production of machinery and equipment also begins in that phase, since the expansion of demand for consumer goods would stimulate an increase in the supply of certain types of machinery that domestic industry would be technological able to produce. Nonetheless, most of the capital goods used would continue to be imported, particularly those involving more advanced technology; but not all state-of-the-art technology would be exported by the more developed countries. Kaldor considered that the introduction and production of consumer goods is relatively swift and is exhausted when the importsubstitution process for this type of goods is concluded.

To sustain rapid growth rates, the industrialization process has to enter a second phase, in which the consumer-goods-producing sector needs to start exporting its surpluses, thereby making it possible to sustain demand and expand specialization. Argyrous (1996) states that in the first two phases, it would be possible to create the conditions for the economy to specialize in the production of capital goods, which leads to the following phase. ${ }^{3}$ At some point in the industrial development process, reliance on imported technology and capital could hold back output growth. But, at some stage of the industrialization process, the external constraint should presumably be eased, making

\footnotetext{
3 Kaldor (1966) uses the term "specialization" to indicate that the sector competes on an equal footing in the international market in terms of productivity and technology endowment.
} 
it possible to overcome reliance on foreign capital and technology. The third phase would begin when the country started to adopt measures to promote the substitution of capital-goods imports. Kaldor (1970) considered that large-scale investments in the capital goods sector would lead to greater productivity growth and would help raise competitiveness.

In the third phase, the country also needs to develop its own technology, which can be incorporated in domestic machinery and equipment, and consolidate the share of the capital-goods sector in the domestic productive structure. Among other things, measures to develop technological capacity should lead to the creation of new products making it possible to expand exports of more technologically intensive goods, which in turn would compensate for the import growth generated by higher incomes and the consequent increase in endogenous demand. The fourth phase, which completes the industrialization process, corresponds to the stage in which the country becomes a capital-goods exporter. In this phase, the capital-goods-producing sector would have achieved a technological maturity similar to that of the industrialized countries. Kaldor (1966) believed economic growth would increase significantly in this latter phase, driven by domestic and external demand for both consumer and capital goods.

Argyrous (1996) considers that success in exporting capital goods follows a lengthy cumulative development period driven by mass production in domestic industries using capital goods. Economic policies that restrict the production of capital goods could therefore obstruct the virtuous growth circle.

The thesis set forth in this article in relation to the Brazilian economy is that, although Brazil had already developed a complex industrial fabric in the period between the end of World War II and the mid-1980s, according to Kaldor's theory it had not progressed fast enough, basically because the final phases of development had not been completed (see section III.A). ${ }^{4}$ a clear indicator of the incomplete nature of the process is the fact that the trade balance displays a structural deficit in more technology-intensive goods, which means that the country is a net importer of capital goods (see section III.B). Moreover, in the last few years since 2004, the domestic and international situations have not favoured the industrialization process (see section III.C), and Brazil has become one of the world's slowest growing emerging economies.

\footnotetext{
4 For an evaluation of the major influence of Brazil's industrial sector on the growth rate of manufacturing industry and other sectors of the economy, see Nakabashi, Scatolin and da Cruz (2010).
}

Kaldor's theory of development phases can be complemented with the analysis made by Fajnzylber (2000, p. 871), according to which it is essential that an economy, including an industrialized one, has an "endogenous core of technological dynamism" to overcome the external vulnerability of growth. Several development authors agree with this idea. For example, Furtado (1984) argues that a developing economy with an incomplete industrialization process would have to resort to "creativity" to promote growth, in other words technological innovation. Furtado (1984, p. 27) also suggests that the lack of creativity in Brazil reflects the fact that its late industrialization occurred in the form of imitative development. Fajnzylber (1983, p. 286) argues that development of the capital-goods-producing sector would not be sufficient, and an "endogenous core of technical progress" would need to be created, technologically strengthened and articulated with the entire productive system to provide it with dynamism and achieve the productive excellence necessary to penetrate and remain in the international market. ${ }^{5}$

The development of this core would reflect the evolution of the economy in its third and fourth phases. On this path, technological progress becomes a key factor for increasing productivity growth and making the economy more competitive; but also to make it possible to expand exports based on the income generated by technology, which in turn would help mitigate the external constraint on growth. Consequently, and thus concluding the industrialization process, economies that are capable of developing and absorbing new technologies change the sectoral structure of industry and disseminate technical changes throughout (Cimoli and others, 2005, p. 12).

Kaldor's description of the industrialization process by stages is related to his thesis on role played by manufacturing industry in the economic growth process, known in the literature as "Kaldor's laws". 6

\footnotetext{
${ }^{5}$ Fajnzylber (1983) considered that the lack of a well-developed capital goods producing sector, given the incomplete nature of industrialization in Latin America, was one of the basic causes of the chronic trade deficit of its economies, and had also prevented them from achieving levels of productive excellence.

6 Kaldor did not present his postulates as economic "laws", but they are known as such in the history of economic thought. The author probably contributed to that himself by not questioning their definition as laws in the debate following their presentation. The fact that Kaldor did not explicitly defined his postulates as "laws" has given rise to differences of interpretation as to their number, which varies between three (Targetti and Thirwall, 1989) and four (Targetti, 1992). This article adopts the latter position.
} 


\section{B. Kaldor's laws and growth conceived as industrial development}

Kaldor's analysis of development phases is complemented by "Kaldor's laws" explaining the dynamic of economic growth. In the 1960s and 1970s, Kaldor developed a set of theoretical proposals that depart from the neoclassical approach, in explaining countries' different growth dynamics in terms of factors related to aggregate demand. After formulating his growth theory based on capital accumulation and the distribution of income in the 1950s and early 1960s, Kaldor envisaged a growth model based on the principle of circular cumulative causation, which paid special attention to changes in the productive structure. In his opinion, aggregate demand levels across countries reflected differences in their productive structures, for which reason he saw the manufacturing sector as crucially important for economic growth, since that sector would enjoy increasing returns to scale, which would help increase productivity throughout the economy.

Kaldor (1966 and 1970) formulated a set of laws that used stylized facts to explain the dynamic of capitalist economies and, in particular, the differences between their growth rates. ${ }^{7}$ Kaldor's laws postulate the following:

First law: There is a positive relation between growth and the aggregate output of the manufacturing sector, such that the higher the growth rate of that sector, the higher is the rate of growth of GDP. The industrial sector becomes the "engine of growth" given its dynamism and dissemination of innovations. The internal linkages within the manufacturing sector and its linkages with other sectors induces productivity growth both inside and outside. When industry has increasing returns, changes in the productive process are disseminated on a sustained and cumulative basis.

Second law: There is a positive relation between the rate of growth of productivity in the manufacturing sector, and growth of the respective output, owing to a causation relation whereby the higher the growth rate of that sector, the faster is also the rate of productivity increase. This law is known as the "Kaldor-Verdoorn law". An increase in output induced by an expansion of demand leads to productivity growth in sectors that

\footnotetext{
7 Kaldor did not perform econometric tests using developing country data, but his arguments aroused great interest among several of his followers, which made it possible to expand his model and test it in other economic contexts.
}

have dynamic economies of scale. This law explains why trading relations between the manufacturing sector and other sectors of the economy make it possible for the first law to be satisfied.

Third law: The higher the growth rate of exports, the greater is the increase in GDP. According to Kaldor, in the more advanced phases of economic development, GDP growth would be fuelled by increasing export demand. This idea assumes that the expansion of industrial activity would raise productivity in the manufacturing sector, which would enhance the competitiveness of exports and stimulate their growth. This, in turn, would lead to an increase in the economy's overall GDP. This development model would translate into a cumulative growth process based on increasing returns in the manufacturing sector. The cumulative causality relation reflects the existence of dynamic and increasing returns to scale in the industrial sector, stemming from the technical progress stimulated by the expansion of output. The existence of economies of scale raises industrial productivity, which generates greater income for firms and, hence, expands their investment capacity. Consequently, manufacturing growth would boost productivity and help to speed up technological change throughout the economy, thereby strengthening its competitiveness on the external market.

Fourth law: The long-term growth of the economy is not constrained by supply, but by demand; thus, in an open economy, the balance of payments is the main demand constraint on output growth. The sustainability of economic growth would depend on the country's capacity to maintain export competitiveness, which in turn would depend on productivity growth in the manufacturing sector (second law). ${ }^{8}$ This means that output growth, ultimately conditioned by the trend of productivity and the economy's learning capacity, should occur when the balance of payments is in equilibrium. So growth rates of both industrial productivity and GDP are determined by the rate of growth of exports in relation to the income-elasticity of demand for imports (Thirlwall, 1983).

The balance of payments equilibrium condition shows how exports help to ease the constraint that this imposes through time. If, in the development process, the level of exports fails to increase as needed to cover

\footnotetext{
8 The third and fourth laws are closely related. These two laws were formulated by Kaldor (1970) and subsequently formalized by Dixon and Thirlwall (1975) and Thirlwall (1979).
} 
the additional import expenses, aggregate demand would have to contract in the long run, and this would reduce employment and output. Accordingly, expanding exports is of strategic importance for the sustainability of growth. Nonetheless, according to the Kaldor-Thirlwall model, the effect of exports on GDP growth depends on each country's productive structure. If the economy has not attained a level of industrialization that enables it to exploit the benefits of cumulative causality, policy-makers should implement structural changes that lead towards that development model. Such measures should focus on industries with increasing returns to scale, particularly those producing goods of higher technological content and unit value, in other words industries that make use of a differentiated and science-based technology. ${ }^{9}$

\footnotetext{
9 Prebisch (2000) argues that exports can make a major contribution to mitigating the external constraint on growth. Accordingly the Kaldor-Thirlwall model and Prebisch's centre-periphery model share an interest in the potential effects of balance of payments deficits for long-term growth. Although the first model is based on the developed economies and the second on developing economies, the analysis of the income-elasticity of demand for imports and exports and the
}

In short, Kaldor believes that the capital accumulation incorporated in modern technologies leads to the conception of a sustained process of industrial change and facilitates significant changes in the productive structure, which enables the economy to match that of the countries with the highest productivity levels. This author recognizes that capital accumulation has a double effect on labour productivity, which increases both because workers use better machinery and because of the learning-by-doing process. Consequently, developing economies should adopt a policy aimed at capital accumulation to speed up the industrialization process, since the development of a technologically advanced industrial sector is a fundamental basis for sustaining long-term growth.

effects these have on the growth path of the countries considered in both models produce converging conclusions. Mention should also be made of the vast Schumpeterian literature which corroborates Kaldor's postulates on the dynamic of increasing returns. See Dosi, Pavitt and Soete (1990); Dosi and Fabiani (1994), and Verspagen (1993), among others.

\section{III}

\section{Brazil's industrial structure}

The acceleration of Brazil's industrialization process lasted from the end of World War II until the mid-1980s, with value added by the industrial sector growing from $20 \%$ of GDP in 1947 to $36 \%$ of GDP in 1985. From then on it started to decline, and by 2010 represented little over $15 \%$. From the growth dynamic standpoint, there is a close correlation between the expansion of the manufacturing sector and GDP growth (see figure 1). Until 1980, industrial output grew faster than GDP in most years; but in the 30 years between the external debt crisis in the early 1980s and 2010 , the growth of industrial value added only outpaced GDP on 10 occasions. Accordingly, the years in which the manufacturing sector grew fastest coincide with those of highest GDP growth. Figure 2 shows cumulative growth rates since 1970 and the relation between the expansion path in the industrial sector and the economy at large. Since 1980, in a changing international liquidity context, the manufacturing sector ceased to lead growth of the Brazilian economy.

Given the close correlation that exists between the growth of manufacturing industry and GDP growth, industrial development cycles tend to move in harmony with the cycles of development in the Brazilian economy as a whole. The manufacturing sector expanded rapidly between 1950 and 1980, after which it started to slow. In the period 1981-2008, the industry growth path was affected by periods of high inflation between 1980 and 1994, international liquidity shortage in the 1980s, foreign exchange crises in the second half of the 1990s, and other events that diminished the dynamism of the sector. In this context, there was increasing uncertainty following the change of exchange-rate regime in January 1999, the energy crisis of 2001, the crisis of confidence caused by the election of the first left-wing president in 2002-2003, and the international financial crisis of the last quarter of 2008. Moreover in the 1980s there were changes in the way development policy was managed, specifically economic liberalization and market promoting reforms, which significantly changed the macroeconomic context of industrial development.

Following the adoption of the Target Plan in the 1950s, the government applied an industrial development 
FIGURE 1

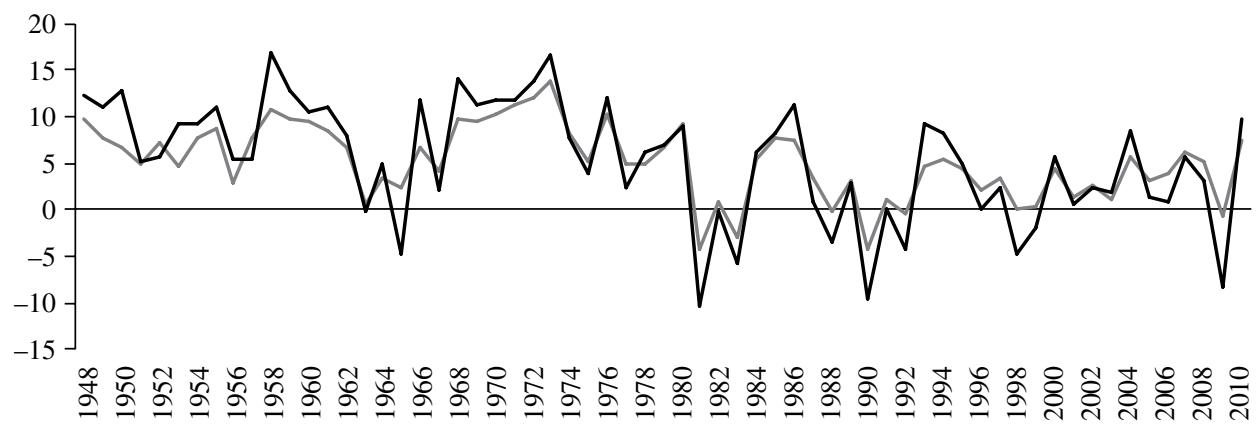

- GDP Value added by the manufacturing sector

Source: National accounts and the economic and financial database (Ipeadata) of the Institute of Applied Economic Research (IPEA) of Brazil. GDP: Gross domestic product.

FIGURE 2

Annual growth of gdp and value added in the manufacturing sector, 1970-2010

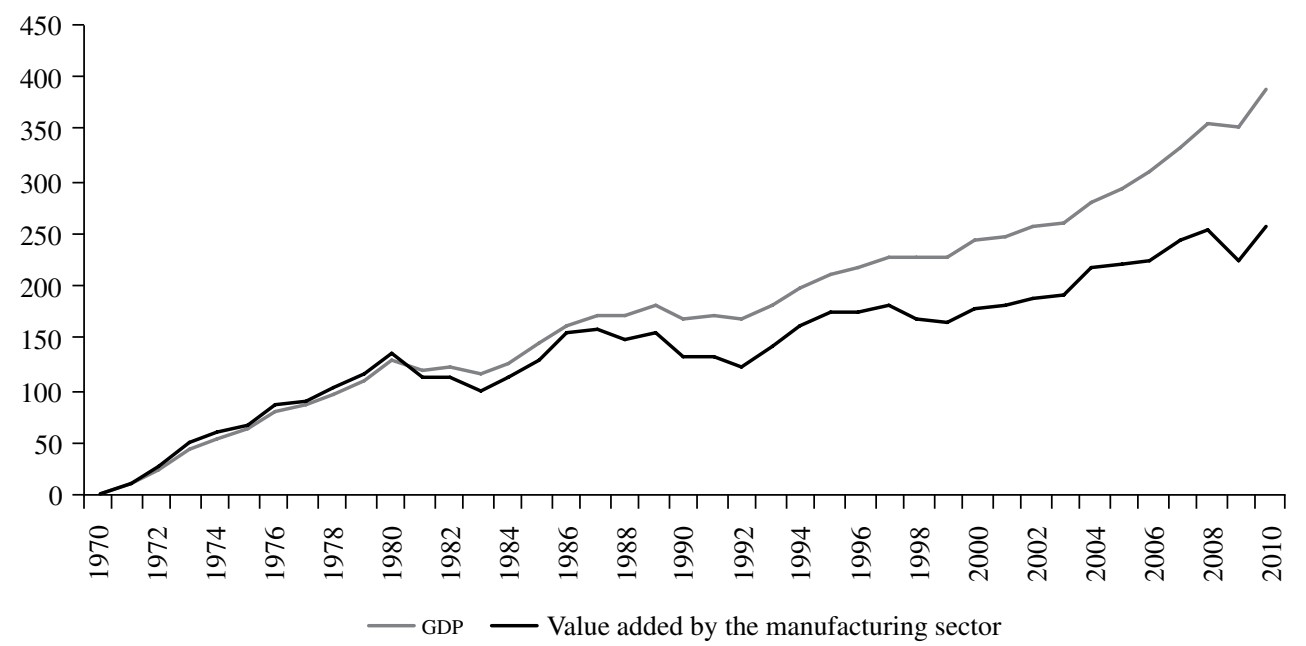

Source: National accounts and the economic and financial database (Ipeadata) of the Institute of Applied Economic Research (IPEA) of Brazil.

a Base $1970=100$.

GDP: Gross domestic product.

policy based on import substitution. In the 1970s, new steps were taken to develop an industrial sector that also produced goods and services based on scientific knowledge and with a differentiated technological base; but the external debt crisis, acceleration of inflation, and, no less important, growth of the public-sector deficit, conspired to interrupt this process. Once inflation had been brought under control in 1994, and in an open macroeconomic context, those industrial sectors did not have an environment that enabled them to increase their share in industrial GDP, which remained unchanged. It can therefore be said that one of the explanatory factors for the reduction in the industrial growth rate since 1980 could be the change in productive structure, which involved a 
relative loss of dynamism in industries producing more technologically sophisticated goods.

Figure 3 compares the growth trend of the capitalgoods-producing sector, in which industries based on scientific knowledge and differentiated technology are concentrated, with the evolution of the manufacturing sector since $1975 .{ }^{10}$ According to the Kaldor postulates, these industries are precisely those that would be in a position to increase the GDP growth rate, insofar as their growth outpaced that of the other industrial sectors. This property relates to the privileged position of the machinery- and equipment-producing sector in the industrial productive chain, since it has tight backward and forward linkages with the other economic sectors. After a rapid growth phase in the 1970s, this sector performed more sluggishly in the 1980s, before expanding by less than the industrial average owing to the economic liberalization of the 1990s. Since 2003, growth has been boosted again by the start of a new cycle of investments in the economy, although this was interrupted by the international financial crisis in late 2008.

${ }^{10}$ From that year on, monthly statistics have been published on the trend of industrial sectors, classified by final destination, compiled through the Monthly Survey of Industry - Physical Production, undertaken by the Brazilian Geographical and Statistical Institute (IBGE).
To provide a more in-depth analysis of the view that the composition of the Brazilian industrial sector has not evolved so as to ease the external constraint on growth, the following subsections review its behaviour since the 1970s in terms of three analytical elements: the changes that have occurred owing to the composition of the GDP of the manufacturing and extraction sectors, by degree of technological intensity; indicators of the evolution of the industrial sector in the different phases of development identified by Kaldor, based on the trade balances of the consumer durables and capital goods sectors; and, lastly, a review of industry after economic liberalization.

\section{A. Brazilian industry since the 1970 s and phases of industrialization}

The import-substitution process supported by development promoting policies should have been completed in the 1980 s, when the share of the manufacturing sector surpassed $30 \% .{ }^{11}$ Table 1 shows the trend of the sector shares in economic activity, classified by type

\footnotetext{
11 See the analyses of the stages of Brazil's industrial development discussed in Bacha and Bonelli (2005) and Lamonica and Feijó (2011), among others.
}

FIGURE 3

\section{Growth in the physical output of the capital goods and manufacturing sectors, 1975-2010}

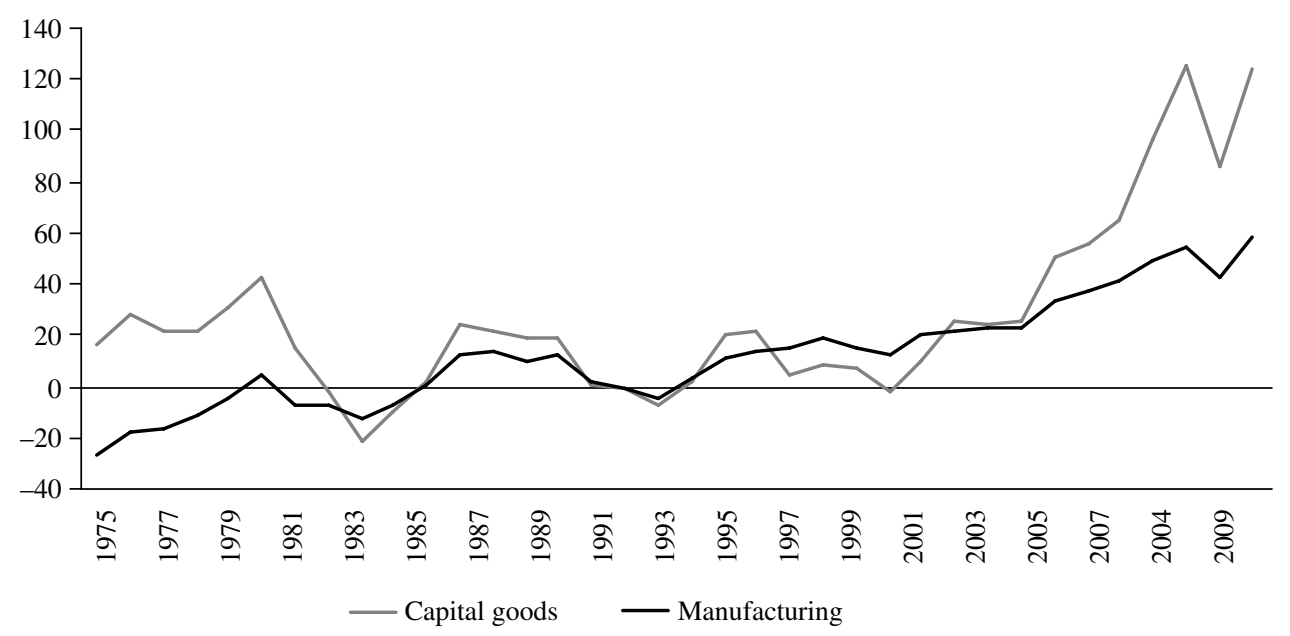

Source: Monthly Survey of Industry - Physical Production undertaken by the Brazilian Geographical and Statistical Institute (IBGE), historical series and new series.

a Base $1991=100$. 
TABLE 1

Percentage share of value-added by manufacturing industry and mineral extraction, according to technological intensity, by sectors 1970, 1985, 1996 and 2007

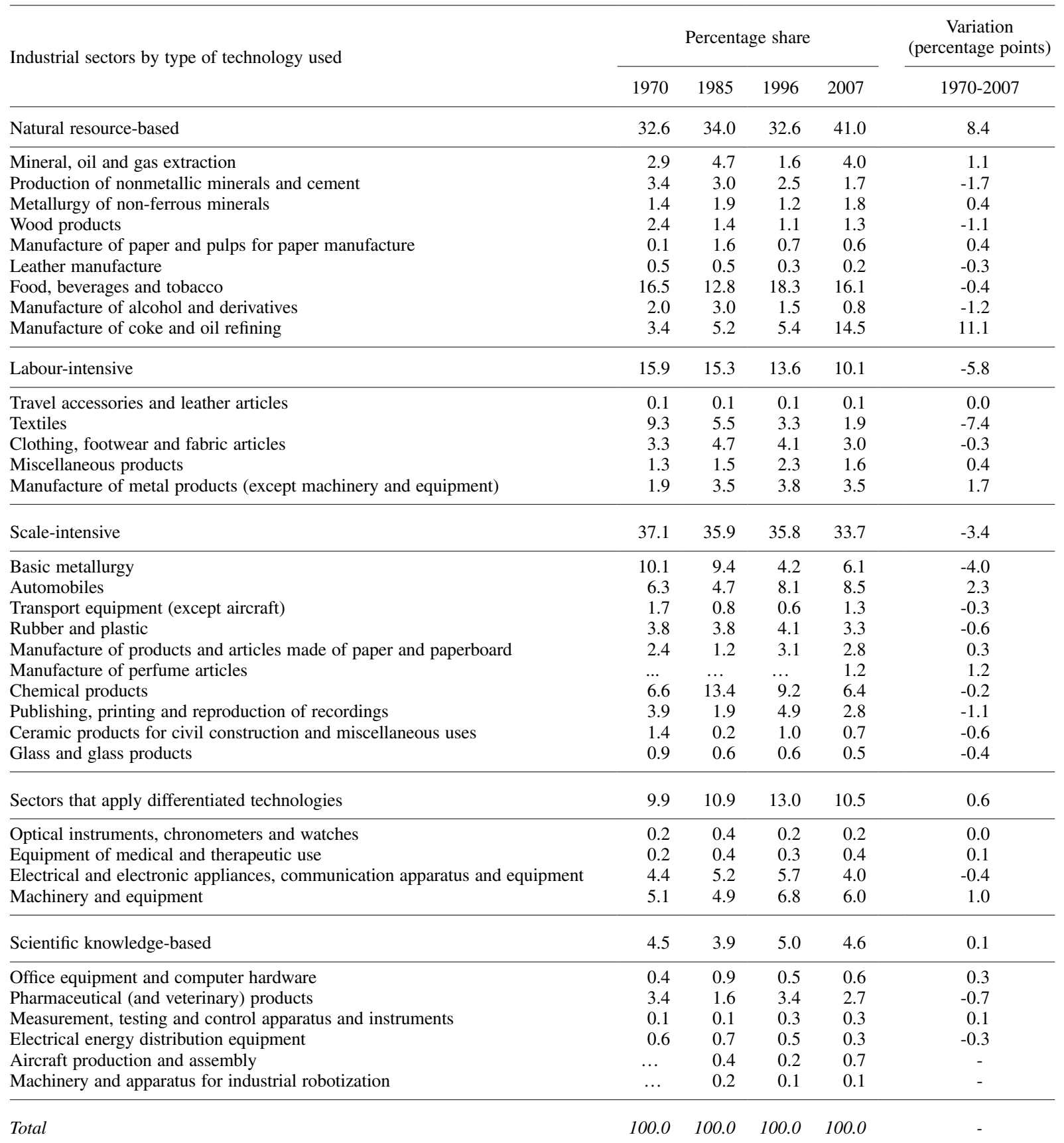

Source: Brazilian Geographical and Statistical Institute (IBGE), Industrial Census of 1970 and 1985 and Annual Industrial Survey of 1996 and 2007. 
of technology used in the selected years. ${ }^{12}$ The table shows that the productive structure obtained from the industrialization process was quite differentiated even in 1970; but there was very little representation of sectors based on differentiated technology and scientific knowledge. Two development programmes were implemented in the 1970s: the first National Development Plan, which lasted from 1968 to 1973; and the second National Development Plan from 1974 to 1979. These made it possible to consolidate the process of diversifying Brazil's industrial structure, but without the parallel creation of a technological innovation development core. The existence of a differentiated industry, specialized in medium- and low-technology sectors, lasted into the following decade, when the most important changes in the productive structure occurred in industries that make intensive use of natural resources and labour, and also in scale-intensive industries.

The contribution to value-added made by high- and medium-high technology sectors, which form part of the Brazilian industrial sector based on differentiated technologies and scientific knowledge, increased, because they required a larger contribution of capital and technology. In the first case (sectors based on differentiated technologies), their share of industrial value-added rose by $0.6 \%$ between 1970 and 2007, and their share of total value added was about $10 \%$; whereas in the second case (sectors based on scientific knowledge), the contribution to value-added increased by just $0.1 \%$, for a total contribution of around $5 \%$ in that period.

Given Brazil's comparative advantages and its continental size, it might be expected that the process of consolidating its industrial fabric would start in sectors specialized in basic industrial products. In fact, in 1970, sectors engaged in the intensive exploitation of natural resources already contributed over $30 \%$ of industrial value-added, whereas $16.5 \%$ of the total contribution came from the food, beverages and tobacco industries. This share had shrunk to $12.8 \%$ in 1985 , although it increased again in 1996 and in 2007, to reach practically the same level as in 1970 (16.1\%), thus becoming the most important industrial sector. Despite the relative stability of the percentage share of this activity, and

12 The literature on the subject has used this classification widely. See Nassif (2008a), among others. The years were selected on the basis of the availability of official figures. In 1970 and 1985, industrial censuses were conducted, which since 1996 were replaced by the Annual Industrial Survey. Feijó and Carvalho (1999) analyse the availability of official statistics on Brazil's manufacturing sector in the 1990s. taking account of the years of extreme performance, the category of industries specialized in the exploitation of natural resources increased its share by $8.4 \%$ between 1970 and 2007. This increase was basically due to a higher share of activities such as oil drilling and refining, which accounted for $3.4 \%$ of total value-added in 1970, but only about $14.5 \%$ in 2007. The increasing importance of this sector has lasted since the end of the 1990s and reflects the start of a major change in Brazilian industry's participation in world trade.

Labour-intensive industries maintained a share of around $15 \%$ between 1970 and 1985, but this started to shrink from then onwards, so that by 2007 their contribution to total value-added was $10.1 \%$. The most important change in this category occurred in the textile industry, whose share has been declining systematically. The contribution of garment-producing industries fluctuated between a high of $4.7 \%$ in 1985 and 3.0\% in 2007, while the share of industries producing metal products in total value-added consolidated around 3.0\% as from 1985.

The share of scale-intensive industries has also been declining, although their contribution of roughly $30 \%$ to industrial value-added suggests that the first and second phases of Kaldor's chronological sequence in the industrialization of Brazil's manufacturing sector are clearly consolidated. Sectors in this category provide inputs for producing intermediate goods, both consumer and capital goods (basic metallurgy, rubber and plastic, chemical products, ceramic products and glass and glass products), while also encompassing the consumergoods sectors, and the production of vehicles, perfume products and publishing, printing and reproduction of recordings. The greatest changes have occurred in the basic metallurgy sector, whose share decreased from 1970 to 2007, and in the vehicle sector, whose share increased. The chemical products sector accounted for $13.4 \%$ of total industrial value-added in 1985 , the largest share in that year. Since then, its contribution remained around $9 \%$ until 2000, but in 2007 it dropped to 6.4\%, a similar proportion to 1970 .

The shares of sectors based on differentiated technologies and scientific knowledge, which encompass the capital-goods producing sectors, have not changed much between 1970 and 2007. Nonetheless, the average contribution of these categories in the period analysed (almost 15\% of industrial value-added) shows that Brazil's industrialization process has now entered the third phase, by virtue of the expansion and diversification of the productive structure and the large share of the capital-goods producing sector. 
In terms of the chronological sequence of the phases of industrial development, the spread of the industrialization process to more technology-intensive sectors would have been affected, even in the 1980s, by the depreciation of the currency and consequent increase in the cost of imported equipment, as well as by the heightened economic uncertainty stemming from the increase in inflation, among other factors. Currency depreciation and the rise in inflation were caused by greater external vulnerability, which was exacerbated by the Mexican crisis in 1982. In fact, the external debt crisis in the early 1980s interrupted the industrialization process, before the investments had had time to attain a sufficient volume to develop the endogenous core of national production envisaged by Fajnzylber (1983).

Although the industrialization process was interrupted before reaching its conclusion according to Kaldor's four-phase model, there were large trade surpluses in the first half of the 1980s, coinciding with the stage in which the Brazilian economy was subject to a major external constraint. Castro and Souza (2004) attribute these surpluses to the maturing of the structural changes generated by the second National Development Plan, which had been applied in the period 1974-1979.

In brief, comparing the situation in 1970 with that prevailing in 2007 shows that changes in the productive structure were heavily circumscribed. The increase in the relative share of natural-resource-based sectors mirrors the growing importance of the oil industry, whereas the declining relative importance of labour-intensive sectors is caused by the decreasing share of the textile industry. The relative loss of importance of the scaleintensive segment reflects the declining importance of the basic metallurgy industry. The share of industrial categories based on differentiated technologies and scientific knowledge changes little between the first and last year considered in table 1 . All of the above reveals the clear trend of the Brazilian industrial sector towards specialization in natural-resource-intensive activities. Given this propensity, Brazil's industrial structure has proven relatively rigid over the last four decades. Changes in the relative share of the different sectors were more intense between 1985 and 2007, which accentuated the concentration of industry in the production of naturalresource-intensive goods. According to the Kaldor industrial development model, Brazilian industry has not yet attained maturity.

To complement this latter comment, figure 4 uses another indicator to show how Brazilian industry needs to continue making progress to enter the maturity phase. Figure 4 shows the trend of aggregate content in relation to the value of output in the categories included

FIGURE 4

Share of value-added in the value of output of the manufacturing and mineral extraction sectors, by technological intensity, 1985, 1996 and 2007

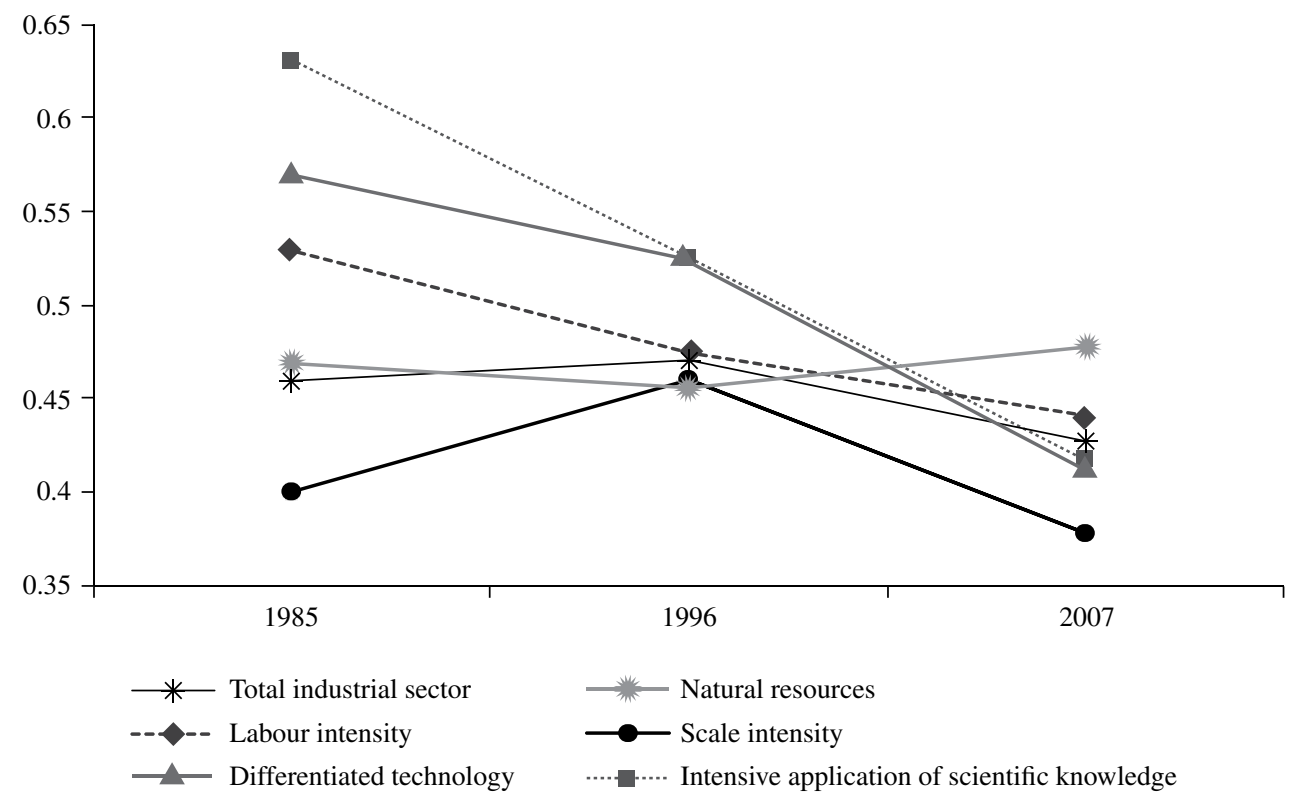

Source: Brazilian Geographical and Statistical Institute (IBGE), Industrial Census of 1985 and Annual Industrial Survey of 1996 and 2007. 
in table 1, for three years: 1985, when a major stage of the import substitution process can be assumed to have ended; 1996, when the effects of the liberalization that began in the early 1980s had already started to appear in the industrial structure; and 2007, the year before the international financial crisis. ${ }^{13}$ Given that the coefficient considered is declining in the industrial sector as a whole particularly in the post-economic liberalization period, it could be interpreted as showing that part of the demand that was previously met by domestic industry has now moved abroad. Several empirical studies highlight this effect as from the 1990s, which led to a deepening of the debate on the country's deindustrialization. ${ }^{14}$

Nonetheless, the industrial organization literature states that this coefficient really measures the degree of verticalization of the industrial sector; so a fall in the indicator would not necessarily mean a relative increase in the use of imported inputs, but, in contrast, could point to an intensification of industrial specialization. In the terms of this article, the question that arises is whether the strengthening of specialization in Brazilian industry which actually occurred, is occurring prematurely, given that the index of value-added of production started to decline throughout industry in 1996, in other words before it could reach maturity. Figure 4 shows that, between 1985 and 1986 the coefficient rose from 0.46 to 0.47 for industry as a whole, and then fell back to 0.43 in 2007. The category of industrial sectors that make intensive use of natural resources is the only one that shows a slight increase in aggregate content between 1985 and 2007 (from 0.47 to 0.48 ). All other categories record a loss in the capacity of domestic industry to add value to the manufacturing process - a loss that is more accentuated in the categories of sectors that make intensive use of scientific knowledge and differentiated technology, and in scale-intensive sectors.

\section{B. Balance of trade in consumer durable goods and capital goods: from consolidation of the industrial sector to the economic liberalization of the 1990s}

The changes that have occurred in a country's industrial structure can also be seen by analysing the international

\footnotetext{
13 The ratio between value-added and the value of output is calculated by dividing the value of industrial processing, used by the IBGE in industrial surveys of the last few years as a variable representing value- added, by the gross value of industrial output.

14 On this point, see the studies performed by the Industrial Development Research Institute (IEDI). See also Feijó, Carvalho and Almeida (2005) and Oreiro and Feijó (2010), among others.
}

trade flow. In terms of sectors that produce final goods, figure 5 shows the trend of the trade balances in consumer durables and capital goods for the period 1974-2010. Brazilian industry was a net exporter of consumer durables from 1977 until 1993, a period in which the economy was still highly protected by customs duties and other trade barriers. The closed nature of the Brazilian economy was also reflected in the technological backwardness of this sector compared to other late-industrializing countries, particularly the "Asian tigers". The trade liberalization of the early 1990s, together with currency appreciation, fuelled an increase in the volume of consumer goods imported, until the exchange-rate regime was altered in 1999. The volume of durable goods exports grew again from the start of the first decade of the new century until 2005, when exchange-rate appreciation caused a new contraction that turned the country into a net importer of consumer durables.

Implementation of the second National Development Plan in the 1970s made it possible to strengthen the capitalgoods-producing sector, which was concentrated in the categories of activities based on the use of differentiated technologies and scientific knowledge, thereby making it possible to make progress in the third phase of the industrialization process. Nonetheless, for the sector to be able to mature, technological development is essential at the national level. Kaldor considers that economic growth and the alignment of a developing economy with the more developed economies requires mature industrial sectors with capacity to create and produce consumer goods locally for both the domestic and the external market. Trade statistics show that the Brazilian economy has not completed the fourth and final phase of industrial development and that, in most years since 1974, trade in capital goods has been in deficit. In the period 19741984, when the capital goods sector consolidated thanks to the application of the second National Development Plan, imports outweighed exports. From 1985 to 1990, there were surpluses, except in 1986 and 1987, reflecting the faster growth of GDP. Since 1991, by which time the economic liberalization process had already begun, net imports of capital goods again grew vigorously, partly because the intensification of domestic competition stimulated a renewal of Brazil's industrial fabric, which was facilitated by exchange-rate appreciation once inflation had been brought under control. In 2003, the country became a net exporter following a fall in the exchange rate, but in 2008 the trade balance started to reverse, and in 2010 it posted a record deficit of US\$ 13.64 billion.

Comparing the figures shown in figure 5 with the information contained in table 1 shows that the 


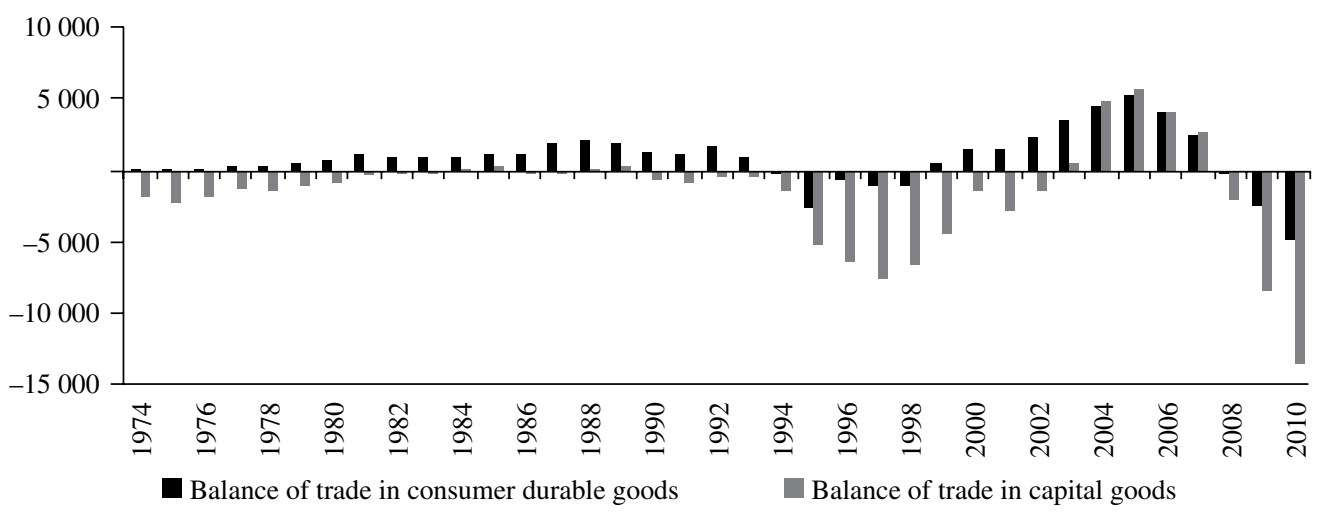

Source: prepared by the authors on the basis of data from the Centre for Foreign Trade Studies Foundation (FUNCEX), and the Economic and Financial Database (Ipeadata) of the Institute of Applied Economic Research (IPEA) of Brazil.

performance of the consumer-goods sector, which encompasses medium-high- and high- technology activities, remains insufficient to provide Brazilian industry with the dynamism it needs to become the engine of long-term economic growth - in other words, to reduce the external constraint on growth. An analysis of trade balances shows that changes in the productive structure over the years have not resulted in an effective increase in the share of the capital-goods sector, which requires further technological upgrading. Since the start of the economic liberalization process, installed industry has shown sufficient dynamism to modernize in terms of processes and the capital stock; but it has not found the momentum needed to make a technological leap that would enable it to start producing goods with a high technological content and high value-added. The absence of an active industrial policy in the economic liberalization stage clearly hampered this stage of the industrialization process.

In a specific study on the behaviour of capital goods imports, (Nassif, 2008b) shows that these were harmed by changes in the macroeconomic environment. The growth of Brazilian capital-goods imports between 1989 and 1998 not only reflects the initial effects of liberalization (1990-1994), but also those arising from a long period of currency overvaluation (1994-1998). In 1999-2006, machinery and equipment imports slackened as a result of the sharp exchange-rate depreciation that occurred between 1999 and 2003 and the low growth rates of the Brazilian economy in the same period (Nassif, 2008b, p. 255). ${ }^{15}$

Kaldor considered that the most dynamic sectors of the economy, which could therefore raise the quality of exports, were those producing high- and medium-hightechnology goods. Figure 6 shows the trade balances of industrial products classified according to their technology intensity as from 1989, to demonstrate that economic liberalization and the consequent modernization of the industrial production process did not cause a reversal of the trade balance in goods of high- and mediumhigh-technology content. The persistent exchange-rate appreciation, which began with price stabilization in 1994 and, since 2004, the vigorous expansion of domestic demand, served to increase the deficit in this industrial category (high- and medium-high- technology goods) (see figure 7). While the over-valued exchange rate lowered the cost of imported capital goods, it has also made it harder to produce them domestically. Consequently, the deficit of the high- and medium-high-technology sector reflects the fact that Brazil is a net technology

\footnotetext{
${ }^{15}$ Nassif (2008b) notes that the sector is producing pumps, compressors and transmission parts; generators, transmission and electric motors; metallic structures and heavy boiler equipment, tanks and boilers. Meanwhile, machinery and tools that account for a larger share of capital goods exports have lost comparative advantage (Nassif, 2008b, p. 258), indicating a loss of efficiency among the traditional or developed sectors in Brazil.
} 
FIGURE 6

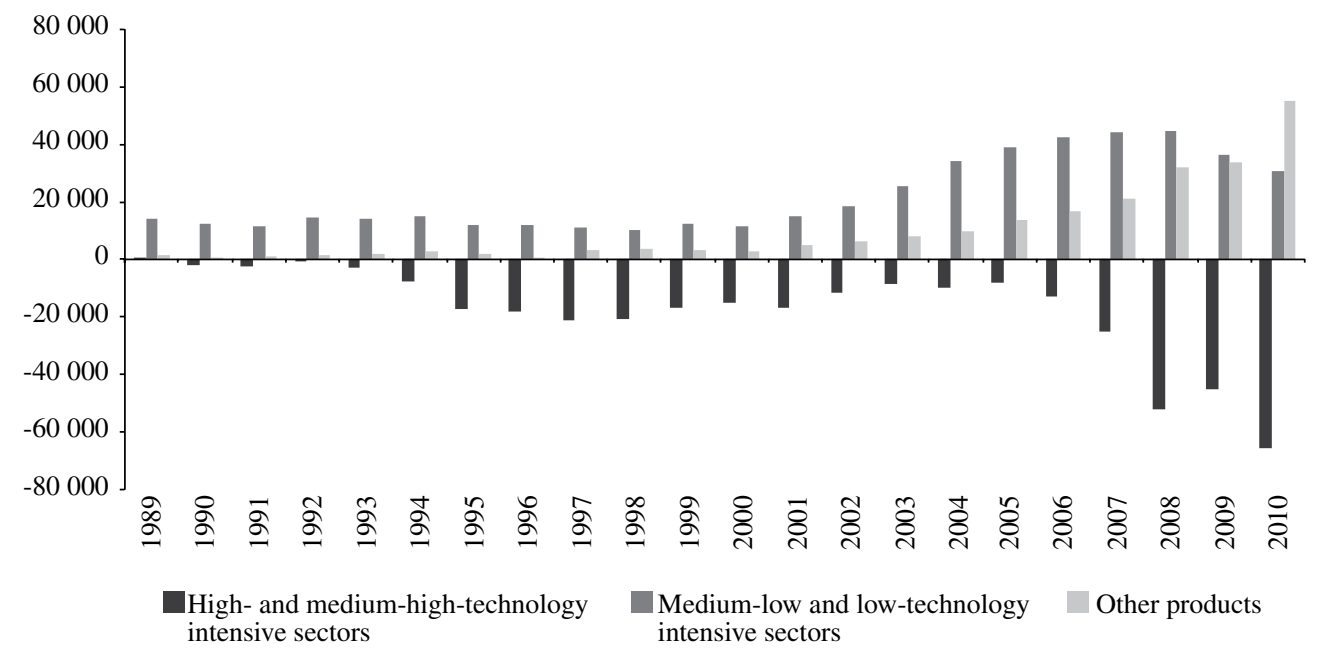

Source: prepared by the authors on the basis of data from the Industrial Development Research Institute (IEDI). (Deficit of US\$ 34.8 billion in the manufacturing sector) US\$ bilhões de déficit nos bens da indústria de transformação, Carta No. 451, 2011 [online] www.iedi.org.br/cartas.

FIGURE 7

Real effective exchange rate, 1990-2010

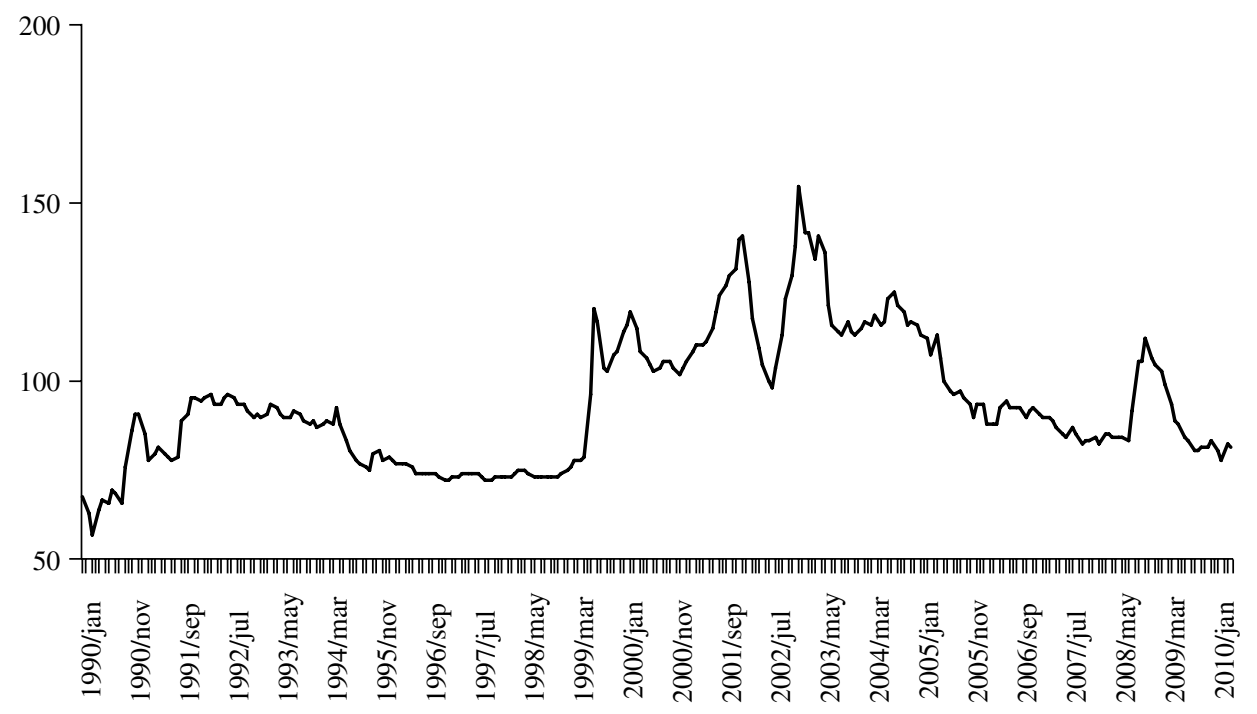

Source: Central Bank of Brazil. 
importer. The technological backwardness that this represents for the country shows that, in the long term, it is specializing in the production of low-technology goods and commodities, of which it is a net exporter. Although the trade balance has not been in deficit over the last decade, in general commodity exports have largely covered the deficit that the manufacturing sector has been accumulating since 2007 (IEDI, 2011).

The growth of net commodity exports, together with an over-valued exchange rate, would not sustain longterm growth in view of the sector's scant contribution to rapid growth. Moreover, the maintenance of an appreciated exchange rate over a long period tends to cause a reallocation of resources that harms development and the domestic production of high- and medium-hightechnology goods. Given the exchange-rate appreciation trend, the cost of importing industrial goods with higher technological content is less than the cost of producing them domestically. Thus, Brazil is moving in the opposite direction to that proposed by Kaldor and by structuralist theory as set out in the classic texts of Furtado and Fajnzylber, among others. Apart from the technical advances applied to the production of commodities, product or process innovations tend to come from abroad, which means that the "endogenous core of technical progress" would be oriented towards increasing the comparative advantages of the production and marketing of commodities, and that the incomeelasticity of demand for imports would continue to exceed the income-elasticity of exports.

Accordingly, although the productive sectors had already consolidated the first and second phases of industrialization and embarked on the third phase, the conditions did not exist for Brazil to catch up the industrialized countries after economic liberalization. This alignment can only happen when industrial-sector specialization leads to higher value-added in production, greater technological content, and greater dynamism in terms of a larger spillover effect on other sectors of the economy. Among other things, this process could lead less structural heterogeneity and better functional distribution of income. The trend of the industrial sector over the last few years shows that major changes are occurring that could be decisive for its transformation.

\section{Recent industrial process and "Dutch disease"}

An important factor for fulfilling the "Kaldor Laws" is the principle of circular cumulative causality. According to this principle, the increasing returns that start to appear in the manufacturing sector, after a given stage in the technological development of the productive structure, can be expected to enhance the competitiveness of exports, which in turn would help increase aggregate output. The interpretation of the recent structural changes in Brazilian industry shows that as the development phases have remained incomplete, the advantages of circular cumulative causality possibly do not materialize. To catch up the more advanced economies and ensure that cumulative causality functions in a virtuous manner, other forces are needed apart from market incentives, such as industrial and technological policies to induce the necessary changes in the productive structure. Moreover, policies that encourage import substitution in high-technology goods are even more necessary when the exchange rate has been appreciating on a sustained basis, as has been the case in the Brazilian economy since price stabilization, and particularly since 2004.

Economic liberalization in a context of price stability and exchange-rate appreciation has had a positive influence on the industrial sector, ${ }^{16}$ by stimulating changes in the allocation of productive resources towards modernization of production processes. ${ }^{17}$ Nonetheless, modernization of the productive structure occurred despite the relatively low level of investment., Although the investment rate in the Brazilian economy was around $22 \%$ in the 1970 s, it fell to around $17 \%$ between 1990 and 2010. The economic and financial liberalization of the early 1990s, together with market-oriented institutional reforms, provided a new macroeconomic scenario for private decisions, in which the competitive dynamic was stimulated. ${ }^{18}$ Exchange-rate appreciation, together with the removal of tariff and nontariff barriers, made imported final products more competitive, thus generating a new pattern of competition with domestic production. This setting called for the modernization of productive processes and the introduction of new products, while exchange-rate appreciation also facilitated lower prices for imports and capital goods, thus contributing to the modernization of

\footnotetext{
16 There is an extensive literature on the effects of economic liberalization for the industrial sector. See, Feijó (2003), Castro (2003) and Ferraz, Kupfer and Iootty (2004), among others.

17 Industrial productivity remained unchanged from the mid-1980s, but improved in the first five years of the 1990s, thanks to trade liberalization. Nonetheless, there was a pronounced decline in employment in industrial sectors, since output expanded without a significant increase in the capital stock. See the analyses of the evolution of industrial productivity in Brazil contained in Bonelli (1996), Bacha and Bonelli (2005), Feijó and Carvalho (2002), and Nassif (2008a), among others. Nassif (2005) analyses the consequences of trade liberalization for the pattern of Brazil's of foreign trade.

18 Erber (2010) reviews the changes that occurred in the macroeconomic scenario, specifically the emergence of a new development consensus.
} 
production processes. Nonetheless, market forces alone were insufficient to induce a deeper structural change, which would have enabled the economy to make process in industrialization according to the sequence set forth by Kaldor.

Over the last few years, what explains the structural shift in favour of greater productive specialization is the combination of an over-valued exchange rate, particularly since 2004, and an improvement in the terms of trade. Between 2004 and 2010, the real appreciated by about $60 \%$, and the terms of trade rose by roughly $35 \%$. The continuation of the appreciated exchange rate reduced the competitiveness of scale-and labour-intensive sectors, which resulted in a loss of share for those sectors within the productive structure. The terms-of-trade improvement favoured natural-resource-intensive sectors. Although the rise in commodity prices had a positive influence on economic growth, even in the context of an appreciated exchange rate, it accentuated the trend towards industrial specialization in those sectors. Table 1 shows that the period 1996-2007 saw progress in the productive structure of natural-resource-intensive sectors, among others, mineral extraction, oil refinery, and the food, beverages and tobacco, as well as scale-intensive sectors such as basic metallurgy.

In view of the above, the rise in the terms of trade could be leading to the economic predominance of natural-resource-exploiting sectors to the detriment of others, which would contribute to the contraction of the industrial sector. This effect is related to one of the forms of "Dutch disease": expansion of the commodity sector and relative stagnation of the industrial goods sector. ${ }^{19}$ Accordingly, persistent exchange-rate appreciation caused by an increase in net exports, compounded by increased demand for natural resources (mineral or agricultural commodities), could trigger a deindustrialization process unless policies are applied to counteract the negative effects of currency appreciation for industry, or if the policies applied for that purpose do not have much effect. The transmission mechanism for deindustrialization caused by "Dutch disease" would consist of a rise in the profitability of commodity exports and a fall in the profitability of other sectors. In the case of the current Brazilian economy, the exchange-rate appreciation trend shown in figure 7 would reduce the competitiveness of the

19 The term "Dutch disease" was originally coined to describe the decline of the manufacturing sector in the Netherlands, following the discovery of large gas reserves in the North Sea in the 1960s. Since then, the term has tended to be related to the "curse of natural resources", although, strictly speaking, "Dutch disease" would be one manifestation of that curse. domestic industrial sector and strengthen the propensity towards stagnation in sectors based on differentiated technologies and scientific knowledge, while also causing a contraction of labour-and scale-intensive sectors, by raising foreign currency production costs in the stagnated sectors. The exchange-rate appreciation trend of the first decade of the new century has lasted on a sustained basis since mid-2004, and was only interrupted in the second half of 2008 owing to the worsening international financial crisis.

Nonetheless, the declining relative importance of industry for long-term growth should not only be attributed to the recent improved terms of trade. Monetary policy management, which maintains a high interest-rate spread that attracts foreign-currency inflows in excess of balance of payments financing needs, as shown by the surplus on the capital and financial accounts, is one of the factors fuelling currency appreciation, which undermines the competitiveness of the industrial sector in the case of Brazil. ${ }^{20}$ Figure 8 shows the evolution of the balance of payments accounts as a proportion of GDP as from 1990. The trade balance has been positive since 2000 , and it has contributed to positive current account balances since 2003. These turned negative from 2007 onwards, despite abundant inflows of external resources, which have generated an excessive accumulation of international reserves, representing $15 \%$ of GDP in 2009. In addition to the pressure exerted by rising terms of trade, monetary policy has magnified the potential effect of "Dutch disease" and prolonged the exchangerate appreciation by maintaining the high interest-rate spread and attracting capital inflows.

It could therefore be argued that, even in a context of rising terms of trade, the trend declining share of the Brazilian industrial sector cannot be defined as a classic case of "Dutch disease" reflecting "the curse of

20 Kaldor (1965, pp. 49 and 50) analyses the negative effects for development of an overvalued exchange rate, and calls for an exchangerate target to be set through economic policy. In the case of excessive appreciation, a medium and long-term target should be set. According to Kaldor, "the correct amount of devaluation [...] presupposes strongly deflationary internal policies while the process of structural adjustment is going on, as well as a succession of downward adjustments in the exchange rate and not a single, once-for-all adjustment. The reason for this is that the acquisition of new markets and the adaptation of the internal production structure in favour of "international goods" takes time, and the exchange rate that may ultimately be necessary to attain the "target", whether this is stated in terms of a share in world trade or in terms of a strong balance of payments position sustained without import restrictions, would represent an "excessive adjustment" if adopted initially — excessive, in that the economy could not respond to the changing relative prices, which would, consequently, the largely nullified by inflation." 


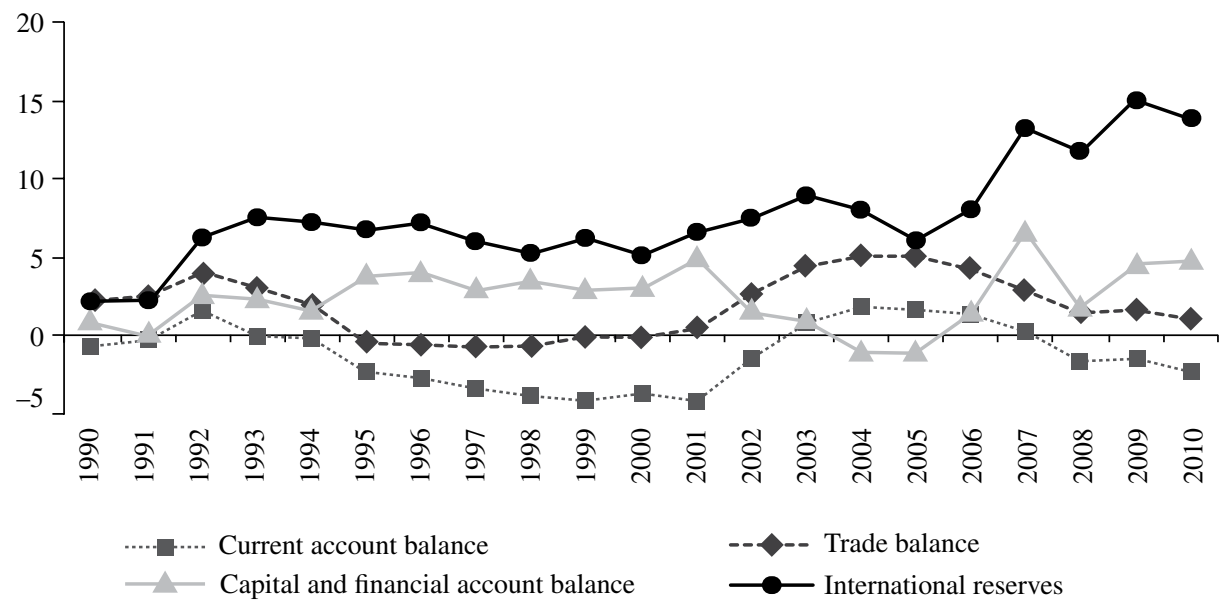

Source: Central Bank of Brazil.

GDP: Gross domestic product.

natural resources". Moreover, the discovery of natural gas and petroleum in the pre-salt strata ${ }^{21}$ in 2006 cannot be seen as a potential cause of "Dutch disease", since exploitation has not yet begun on a large scale. The relative deindustrialization of the Brazilian economy basically reflects the rising terms of trade for commodities, of which the country has abundant supply, and the exchangerate appreciation trend sustained by a monetary policy that maintains a large interest-rate spread in a context of high international liquidity. The second factor is no less significant than the first. ${ }^{22}$

Following Kaldor's logic, the positive effects of the commodity export boom since 2003 should have been harnessed to finance investments to promote growth in the more technically advanced sectors, to regain the import-substitution process and make it possible to ease the external constraint on solid foundations. This would require investments to expand the faster

\footnotetext{
${ }^{21}$ Geological strata formed before an extensive layer of salt, which can be more than $2,000 \mathrm{~m}$ thick.

22 Generally speaking, the debate on Brazilian "de-industrialization" has focused more on rising commodity prices than the role of monetary policy. See, among others, Bresser-Pereira (2008). Nassif, Feijó and Araújo (2011) analyse the factors that explain the change recorded in Brazil since 1999, giving prime importance to the interest rate spread. It should also be remembered that the post-Keynesian literature states that capital flows in emerging economies tend to be procyclical. See Resende and Amado (2007).
}

growing industrial sectors. Consequently, the increased import capacity should have been reversed, to expand possibilities for absorbing technological process through capital accumulation. As Salter pointed out many years ago (Salter, 1966, pp. 153 and 154), a high rate of investment is needed to change the productive structure rapidly and, depending on demand, generate increased output and higher productivity in sectors where faster technical progress is possible.

Pérez (2008) argues that the income generated by the commodity sector could finance a "jump to development". This would depend on sustained technological updating of natural resource-based activities, which would gradually improve the export profile through continuous innovation of products, activities and related processes; and it would create goods of high value-added based on the traditional commodity market. The success of a strategy of this type might largely depend on the coordination of a developmentoriented economic policy, which leads to the creation of an "endogenous innovation nucleus" based on the favourable circumstances offered by the exploitation of natural resources in terms of generating demand.

The situation that has prevailed in Brazil over the last few years does not match that description. Cimoli and others (2005, pp. 32 and 33) note that the existence of abundant natural resources can sustain high growth rates for a time, without the need for major investment to create technology; but the availability of natural 
resources alone cannot sustain long-term growth. There are two reasons for this:

(i) Growth based on factor abundance does not promote structural change; and the increased productivity throughout the economy reproduces undesired situations of distributive inequality, poor job quality, and structural heterogeneity; and

(ii) Growth is more vulnerable to changes in the international economy and the behaviour of external demand. This leads these authors to conclude that the economy is less vulnerable when the source of growth is income contributed by technology and knowledge production, which makes it possible to respond to changes in the competitive framework. In contrast, it is much harder for that to happen when the income source is highly dependent on an abundant resource, owing to the lack of technological capacity needed to adapt the economy to the new context.

According to the Kaldorian-structuralist literature on economic growth, therefore, in Brazil over the last 30 years the larger share of industrial sectors based on natural resources in the productive structure implies slower long-term GDP growth and greater vulnerability to external crises, particularly those involving a slump in external demand. This means that the long-term GDP growth rate, in a framework of balance of payments equilibrium, will be lower than what it could be, particularly compared to the rapid growth period in the context of development-oriented policies. If industrial sectors based on differentiated technologies and scientific knowledge grew at least as fast as natural-resource-based sectors and the agriculture and service sectors, they could give the Brazilian economy long-term growth rates above those achieved in the last decade, such as

\section{IV}

\section{Final comments}

Intensification of the current trend of Brazilian industry toward specialization in natural-resource- intensive sectors, together with a relative contraction of sectors that make intensive use of technology, especially those producing capital goods, will move Brazilian industry away from the maturation process posited by Kaldor. Moreover, following the interpretation of this author, not all possibilities for development of Brazilian those achieved in the period between the end of World War II and 1980. Clearly, the stimulus to rapid growth in industrial sectors based on differentiated technologies and scientific knowledge, and the expansion of their share in industrial GDP, would respond to an industrial policy oriented towards the development of an endogenous technology core -in other words State participation is the source of incentives for industrial development oriented towards an increase in the technological content of the goods and services produced in the country. The recommendation made by Ocampo and Vos (2008), for peripheral economies to expand the scope of policies to promote sustained growth, can be interpreted in the same way.

Brazil's current productive structure, and its reflection in the trade balance, are the outcome of the historical industrial and economic development process. According to Kaldor (1966 and 1970) and Fajnzylber (1983), if industry had diversified more intensively, the structure would remain incomplete owing to its relatively small share in industrial GDP and the recurrent trade deficit of the technology-intensive sectors. Moreover, the ongoing exploitation of Brazil's abundant natural resource endowment, in a context of rising terms of trade, has the corollary of exchange-rate appreciation that is magnified by the interest-rate spread, and industrial weakening that starts in technology-intensive sectors. According to the approach followed by Kaldor (1966 and 1970) and Fajnzylber (1983), "Dutch disease" will set a trap for the development process by restricting the growth of the more technologically intensive industrial sectors. In the case of Brazil, the trap could arise when the exploitation of oil and natural gas reserves from the pre-salt strata reaches its peak, which would turn the country into a large-scale exporter of those commodities. industry offered by the industrialization process have been exhausted.

In terms of Kaldor's development phases, the Brazilian productive structure faces the challenge of deepening phases three and four to reduce the external constraint on growth, particularly in relation to sectors based on differentiated technologies and scientific knowledge. Consequently, the main obstacle 
to exploiting the country's long-term growth potential is not the declining share of industrial output in GDP, but the stagnation or shrinking share in industrial GDP of sectors that make very intensive use of technologies. According to Kaldor's cumulative causality mechanism, lack of progress in the industrialization process will lead to less favourable participation in trade flows, thereby lowering the Brazilian economy's long-term growth rate, which could become trapped in a vicious growth circle, rather than evolving in a virtuous circle.

The economic liberalization since the 1990s, together with exchange-rate appreciation have contributed to a structural change in industry. Although that change has helped modernize the industrial fabric, it has also discouraged exports and the creation and production of national technology, owing to the combined effect of a high real interest rate and exchange-rate appreciation. These would be the first symptoms of "Dutch disease".

The terms of trade increase that started in 2003 has had a positive effect on Brazilian GDP growth since then, even with a lower exchange rate and high real interest rates, which typically discourage exports and investments in high-technology goods. Accordingly, while significant variables such as the exchange rate and interest rates hinder sustained growth, this has been achieved in the current phase through rising prices in the commodities for which Brazil is one of the world's leading producers. It needs to be asked whether this type of growth is sustainable in the long term. Kaldor's theory would suggest not.

As noted by Pérez (2008) and Rodrik (2010), unlike what happens with specialization, the diversification of industrial sectors is essential for sustained economic growth, since it allows for a wider range of productive activities and more balanced shares among the manufacturing sectors. In contrast, the perverse combination that has developed in Brazil between rising terms of trade, an appreciated exchange rate and high real interest rates has had the opposite effect of turning the Brazilian economy into a specialized, albeit modern, economy, and narrowing the range of industrial activities, in other words causing sector concentration. Holland and Porcile (2005, p. 61) argue that specialization in sectors with little or no technological intensity would reduce to capacity of less technologically developed economies, particularly developing countries such as Brazil, to diversify their productive structure on a competitive basis, in other words without the need for tariff protection or falling relative wages. Consequently, attaining the objectives of easing the external constraint and convergence in terms of productivity requires investments in technology that are reflected in the production of consumer goods and durable goods to supply both the domestic and external markets.

(Original: Portuguese)

\section{Bibliography}

Argyrous, G. (1996), "Cumulative causation and industrial evolution: Kaldor's four stages of industrialization as evolutionary model", Journal of Economic Issues, vol. 30, No. 1, Salisbury, Association for Evolutionary Economics, March.

Bacha, E.L. and R. Bonelli (2005), "Uma interpretação das causas da desaceleração econômica do Brasil", Revista de economia política, vol. 25, No. 3, São Paulo, Centro de Economía Política.

Barros, O. and R.R. Pereira (2008), "Desmistificando a tese da desindustrialização: reestruturação da indústria brasileira em uma época de transformações globais", Brasil globalizado, O. Barros and F. Giambiagi (orgs.), Campus, Rio de Janeiro.

Bértola, L. and J.A. Ocampo (2010), Desarrollo, vaivenes y desigualdad. Una historia económica de América latina desde la independencia, Madrid, Ibero-American Secretariat.

Bonelli, R. (1996), "Produtividade industrial nos anos 1990: controvérsias e quase-fatos", Economia brasileira em perspectiva, vol. 2, Rio de Janeiro, Institute of Applied Economic Research (IPEA).

Bresser-Pereira, L.C. (2008), "The Dutch disease and its neutralization: a Ricardian approach", Revista de economia política, vol. 28, No. 1, São Paulo, Centro de Economía Política.

Castro, A.B. (2003), "Brazil's second catch-up: characteristics and constraints", cepal Review, No. 80 (LC/G.2204-P), Santiago, Chile, August.

Castro, A.B. and F.P. Souza (2004), A economia brasileira em marcha forçada, Rio de Janeiro, Paz e Terra.

Central Bank of Brazil [online] www.bcb.gov.br.
Cimoli, M. and others (2005), "Cambio estructural, heterogeneidad productiva y tecnología en América Latina", Heterogeneidad estructural, asimetrías tecnológicas y crecimiento en América Latina (LC/W.35), M. Cimoli (ed.), Santiago, Chile, Economic Commission for Latin America and the Caribbean (ECLAC).

Dixon, L. and A.P. Thirlwall (1975), "A model of regional growthrate differences on Kaldorian lines", Oxford Economic Papers, vol 27, No. 2, Oxford, Oxford University Press.

Dosi, G. and S. Fabiani (1994), "Convergence and divergence in the long-term growth of open economies", The Economics of Growth and Technical Change: Technologies, Nations, Agents, G. Silverberg and L. Soete (orgs.), Aldershot, Edward Elgar.

Dosi, G., K. Pavitt and L. Soete (1990), The Economics of Technical Change and International Trade, New York, New York University Press.

Erber, F.S. (2010), "As convenções de desenvolvimento no Brasil contemporâneo: Um ensaio de economia política", Texto para discussão eclac/ipea, No. 13 (LC/BRS/R.230), Brasilia, ECLAC office in Brasilia.

Fajnzylber, F. (2000), "Industrialização na América Latina: da 'caixa preta' ao "conjunto vazio", Cinquenta anos de pensamento na cepal, R. Bielschowsky (org.), Rio de Janeiro, Record.

(1983), La industrialización trunca de América Latina, Mexico City, Editorial Nueva Imagen/Centro de Economia Transnacional.

Feijó, C.A, (2003), "Produtividade do trabalho e emprego: o duplo desafio para os próximos anos, Agenda Brasil: políticas 
econômicas para o crescimento com estabilidade de preços, J. Sicsu, J.L. Oreiro and L.F. de Paula (orgs.), Barueri, Manole. Feijó, C.A. and P.G.M. Carvalho (2002), "Uma interpretação sobre a evolução da produtividade industrial no Brasil nos anos noventa e as 'leis' de Kaldor", Nova economia, vol. 12, No. 2, Minas Gerais, Federal University of Minas Gerais.

(1999), "O debate sobre a produtividade industrial e as estatísticas oficiais", Economia aplicada, vol. 4, No. 4, São Paulo, October-December.

Feijó, C.A., P.G.M. Carvalho and J.S.G. Almeida (2005), "Ocorreu uma desindustrialização no Brasil?", São Paulo, Instituto de Estudos para o Desenvolvimento Industrial (IEDI) [online] www. iedi.org.br/admin_ori/pdf/20051129_desindustrializacao.pdf.

Ferraz, J.C., D. Kupfer and M. Iootty (2004), "Industrial competitiveness in Brazil: ten years alter economic liberalization", cepal Review, No. 82 (LC/G.2220-P), Santiago, Chile, April.

Furtado, C. (1984), Cultura e desenvolvimento em época de crise, Rio de Janeiro, Paz e Terra.

Holland, M. and G. Porcile (2005), "Brecha tecnológica y crecimiento en América Latina”, Heterogeneidad estructural, asimetrías tecnológicas y crecimiento en América Latina (LC/W.35), M. Cimoli (ed.), Santiago, Chile, Economic Commission for Latin America and the Caribbean (ECLAC).

IBGE (Brazilian Geographical and Statistical Institute), "Censo industrial 1970" [online] http://biblioteca.ibge.gov.br/colecao_ digital_publicacoes_multiplo.php?link=censoindustrial\&titulo= Censo\%20Industrial\%20-\%201960-1985.

, "Censo industrial 1985" [online] http://biblioteca.ibge.gov. br/colecao_digital_publicacoes_multiplo.php?link=censoindust rial\&titulo=Censo\%20Industrial\%20-\%201960-1985.

, "Pesquisa Industrial Anual" [online] www.ibge.gov.br.

, "Pesquisa Industrial Mensal de Produção Física" [online] www.ibge.gov.br.

IEDI (Instituto de Estudos para o Desenvolvimento Industrial) (2011), "US\$ 34,8 bilhões de déficit nos bens da indústria de transformação", Carta iedi, No. 451 [online] www.iedi. org.br/cartas.

Ipeadata [online] www.ipea.gov.br.

Kaldor, N. (1970), "The case for regional policies", Scottish Journal of Political Economy, vol. 17, No. 3, Perth, Scottish Economic Society, November.

(1966), Causes of the Slow Rate of Economic Growth of the United Kingdom, Cambridge, Cambridge University Press. (1965), "The relative merits of fixed and floating rates". Published also in Further Essays on Applied Economics, New York, Holmes and Meier Publishers, 1978.

Lamonica, M.T. and C.A. Feijó (2011), "Crescimento e industrialização no Brasil: uma interpretação à luz das propostas de Kaldor", Revista de economia política, vol. 31, No. 1, São Paulo, Centro de Economía Política.

Marquetti, A.A. (2002), "Progresso técnico, distribuição e crescimento na economia brasileira: 1955-1998”, Estudos econômicos, São Paulo, vol. 32, No. 1,

Nakabashi, L., F.D. Scatolin and M.J.V. Da Cruz (2010), "Impactos da mudança estrutural da economia brasileira sobre o seu crescimento", Revista de economia contemporânea, vol. 14, No. 2, Rio de Janeiro, Federal University of Rio de Janeiro.
Nassif, A. (2008a), "Há evidências de desindustrialização no Brasil?", Revista de economia política, vol. 28, No. 1, São Paulo, Centro de Economía Política.

(2008b), "The structure and competitiveness of the Brazilian capital goods industry", cepal Review, No. 96 (LC/G.2396-P), Santiago, Chile, December.

(2005), "Os impactos da liberalização comercial sobre o padrão de comércio exterior brasileiro", Revista de economia política, vol. 25, No. 1, São Paulo, Centro de Economía Política.

Nassif, A., C. Feijó and E. Araújo (2011), "The long-term "optimal” real exchange rate and the currency overvaluation trend in open emerging economies: the case of Brazil", Discussion Paper, No. 206 (UNCTAD/OSG/DP/2011/6), Geneva, United Nations Conference on Trade and Development (UNCTAD), December.

Ocampo, J.A. and R. Vos (2008), "Policy space and changing paradigm in conducting macroeconomic policies in developing countries", bis Papers, No. 36, Basel, Bank for International Settlements.

Oreiro, J.L. and C.A. Feijó (2010), "Desindustrialização: conceituação, causas, efeitos e o caso brasileiro", Revista de economia política, vol. 30, No. 2, São Paulo, Centro de Economía Política.

Palma, J.G. (2005), "Quatro fontes de desindustrialização e um novo conceito de doença holandesa", paper presented at the Conference "Industrialização, desindustrialização e desenvolvimento" [online] www.iedi.org.br.

Pérez, C. (2008), "A vision for Latin America: Resource-based strategy for technological dynamism and social inclusion", Globelics Working Paper Series, No. WPG0804, Aalborg, Globelics.

Prebisch, R. (2000), "Problemas teóricos e práticos do crescimento econômico", Cinqüenta anos de pensamento na cepal, R. Bielschowsky (org.), Rio de Janeiro, Record.

Resende, M.F. and A. Amado (2007), "Liquidez internacional e ciclo reflexo: algumas observações para a América Latina”, Revista de economia política, vol. 27, No. 1, São Paulo, Centro de Economía Política, January-March.

Rodrik, D. (2010), "Políticas de diversificação econômica", cepal Review, special issue in Portuguese (LC/G.2444-P), Santiago, Chile, May.

Salter, W.E.G. (1966), Productivity and Technical Change, Cambridge, Cambridge University Press.

Targetti, F. (1992), Nicholas Kaldor: The Economics and Politics of Capitalism as a Dynamic System, Oxford, Clarendon Press.

Targetti, F. and A. Thirlwall (1989), The Essential Kaldor, London, Duckworth.

Thirlwall, A.P. (1983), “A plain man's guide to Kaldor's growth laws", Journal of Post Keynesian Economics, vol. 5, No. 3, Armonk, M.E. Sharpe, Inc.

(1979), "The balance of payments constraint as an explanation of international growth rates", Banca Nazionale del Lavoro Quarterly Review, Rome, Banca Nazionale del Lavoro, March.

Verspagen, B. (1993), Uneven Growth between Interdependent Economics: A Evolutionary View on Technology Gaps, Trade and Growth, Aldershot, Avebury. 